\begin{tabular}{|c|c|}
\hline International journal of endocrinology & $\begin{array}{r}\text { Сторінка ремактора } \\
\text { /Editor's Page/ }\end{array}$ \\
\hline
\end{tabular}

\title{
BiA реАактора
}

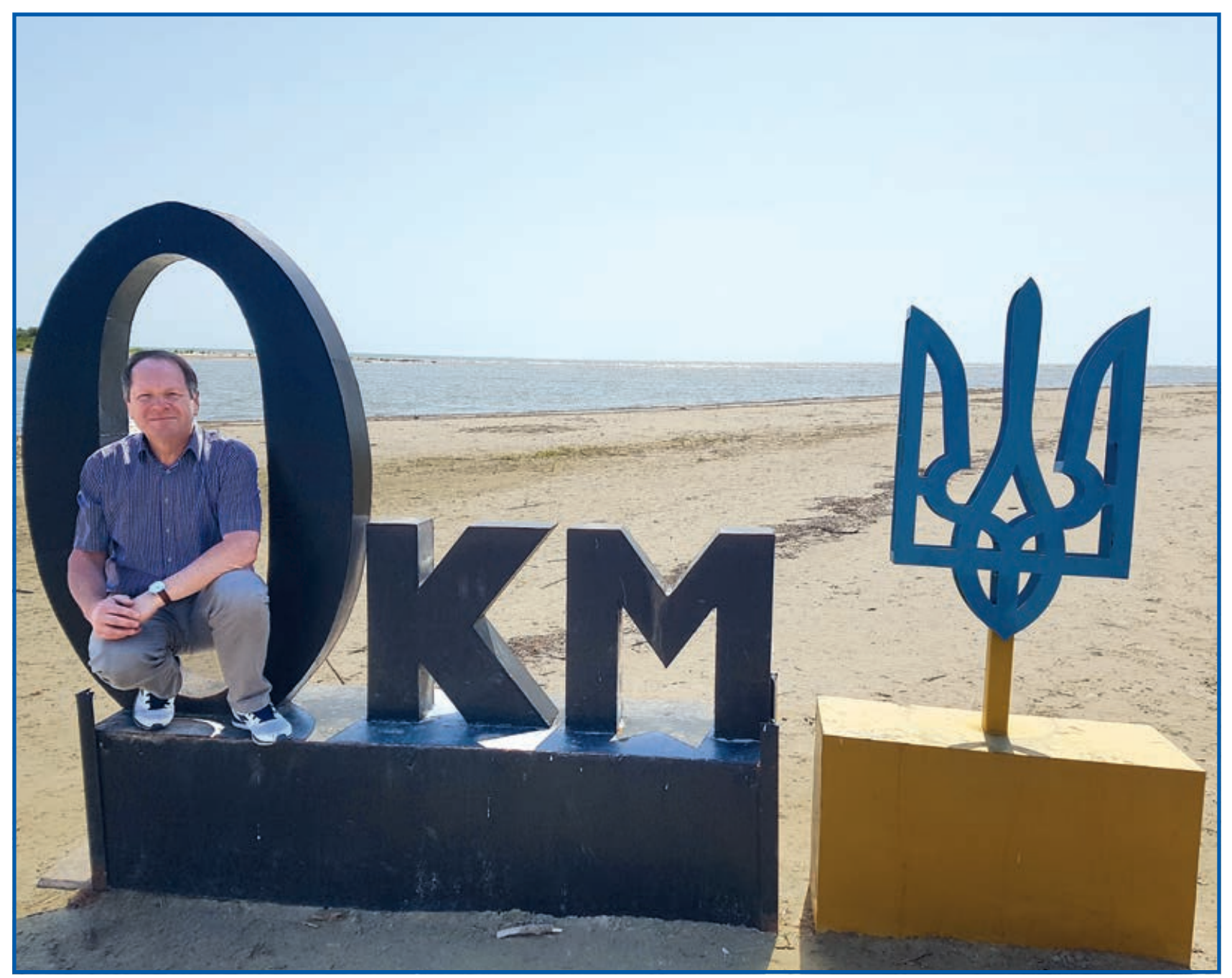

Нещодавно опублікована позиція Американської робочої групи з профілактики захворювань (USPSTF) стосовно скринінгу раку щитоподібної залози (Щ3). На сьогодні не рекомендується проводити скринінг раку ЩЗ у дорослих пацієнтів, у яких відсутні клінічні симптоми. Як стверджують представники цієї робочої групи, аргументів, що обгрунтовують доцільність такого скринінгу, недостатньо. У той же час лікування може призвести до негативних наслідків. Нові рекомендації USPSTF були одночасно опубліковані онлайн у журналі «ЈАMA» і на веб-сайті організації. Слід зазначити, що позиція USPSTF щодо цього виду скринінгу залишається незмінною ще $з$ моменту виходу попередньої версії цих рекомендацій у 1996 р. Очевидно, що ці ре- комендації не стосуються пацієнтів із симптомами раку ЩЗ (осиплість голосу, біль в горлі, утруднення ковтання, поява вузлів, набряклості або асиметрії на шиі).

USPSTF дійшла висновку про відсутність адекватних прямих доказів того, що скринінг раку ЩЗ в осіб без клінічної симптоматики як методом пальпації, так і з використанням ультразвуку покрашує віддалені результати. Рекомендація отримала ступінь D, тобто найнижчу оцінку зі всіх можливих. Це означає, що «є помірний або високий ступінь упевненості в тому, що втручання не має жодних підсумкових переваг або що ризики переважують переваги». Експерти робочої групи також закликають звернути увагу на той факт, що хоча 
впродовж останніх 10 років частота виявлення раку Щ3 щорічно збільшувалася на 4,5 \%, при цьому не відбувалося жодних відповідних змін смертності, і що п’ятирічна виживаність при раку ЩЗ становить $98,1 \%$.

Скринінг будь-яких злоякісних новоутворень виправданий у тих випадках, коли його проведення знижує ймовірність смерті від цього новоутворення або поліпшує якість життя пацієнтів, але в разі раку ЩЗ не відбувається ні перше, ні друге. Це пов'язано 3 тим, що при безсимптомному папілярному раку Щ3 низького ризику (цей тип пухлини найчастіше виявляють при візуалізуючих дослідженнях) ранній початок лікування (тобто ще до появи клінічних симптомів) не покращує прикінцеві результати захворювання.

Крім того, дослідження, у яких у пацієнтів із підтвердженим раком Щ3 відслідковувалася тактика спостереження, показали, що у понад 90 \% випадків невеликий папілярний рак не збільшується в розмірах нерідко навіть упродовж тривалого часу. Це підтверджується також епідеміологічними даними з різних країн, що підтверджують відсутність зниження ризику смерті від цього новоутворення при збільшенні частоти його виявлення. Зокрема, такі дані були показані на прикладі Південної Кореї, де діє урядова програма скринінгу, і США, де рак ШЗ часто виявляється випадково при проведенні візуалізуючих досліджень за іншими показаннями.

Згідно з актуальною статистикою США, від раку Щ3 щорічно помирає лише близько 1600 дорослих, але при цьому приблизно у 250 мільйонів мешканців країни є вузли в ЩЗ. Це означає, що у разі введення популяційного скринінгу величезне число людей після виявлення вузлів потребуватиме діагностичних досліджень та інвазивних процедур, які неминуче будуть пов'язані з несприятливими психологічними наслідками. А в результаті, коли зрештою діагностують певну кількість злоякісних пухлин, вони з дуже великою ймовірністю можуть виявитися такими, що повільно ростуть.

Що стосується потенційних ризиків скринінгу, у виконаному USPSTF систематичному огляді, який охопив 36 досліджень за участю 43295 пацієнтів, частота стійкого гіпопаратиреозу внаслідок операції досягла 5,93 випадку на 100 тиреоїдектомій, а ушкодження зворотного нерва траплялися в 0,99-2,13 випадку на 100 операцій.

Разом із позитивними відгуками на нові рекомендації $є$ й певні заперечення. Опоненти посилаються на те, що, крім вже згаданого зростання захворюваності на рак Щ3, є дані про збільшення смертності від цього новоутворення. Зокрема, за даними аналізу бази даних програми SEER, за період з 1994 по 2013 р. смертність зростала щорічно на $1,1 \%$, хоча йдеться про дуже низькі цифри. Трапляються також дані про ріст числа випадків виявлення пізніх стадій папілярного раку Щ3, що вже не можна пояснити гіпердіагностикою.

Тому, виходячи з цих міркувань, у питанні скринінгу раку ЩЗ рано ставити крапку.

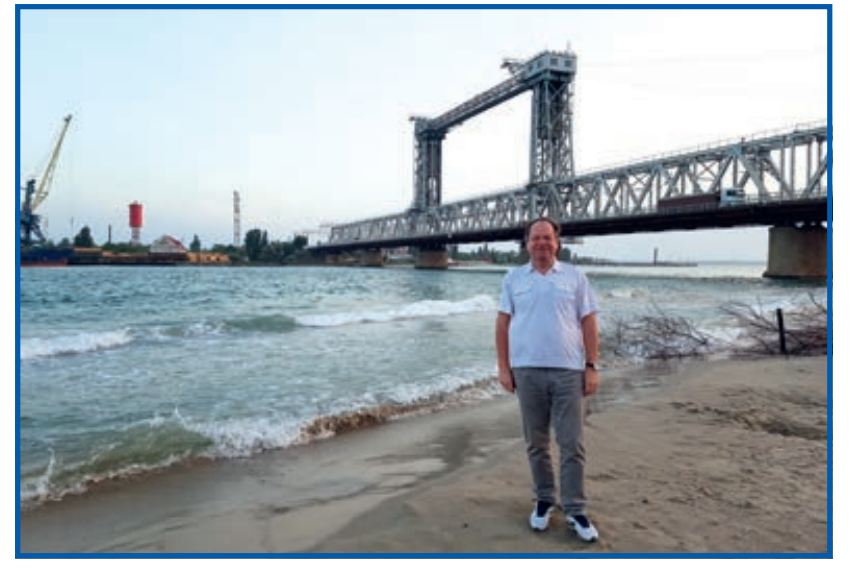

Зустріч Дністра з Чорним морем

Вітання читачам з неповторних цікавих куточків півдня нашої держави!

У першому магічному куточку знак нульового кілометра символізує зустріч двох стихій, величезної ріки і моря, які знайшли свій компроміс в Дунайській дельті.

Ріка дружби Дунай здолала 2860 км територією 10 держав Європи і впадає в Чорне море. 3 огляду на те, що епітети радянських часів сьогодні не в пошані, ріку з позицій нових геополітичних реалій краще йменувати символом європейської інтеграції.

Це місце називають нульовим кілометром саме тут можуть радісно «обнулитися» всі бажаючі. Хоча насправді рукавів Дунаю, де ріка впадає в Чорне море, аж три, але такий знак встановлений лише на одному з них виключно для туристів. За улюбленою байкою екскурсоводів, слід пройти через нуль, щоб обнулити гріхи й додати нуль до зарплати.

А неподалік - українське місто Вилкове, що називають українською Венецією. Незвичайність міста полягає в тому, що стара його частина розміщена на воді. Тому вулицями в місті слугують канали, якими переміщаються переважно на місцевих «гондолах» і моторних човнах - найпопулярнішому місцевому транспорті. По обидва боки каналів і вздовж будинків - дерев'яні кладки-тротуари, якими пересуваються жителі. Більшість населення міста старовіри - липовани, і в цьому унікальність

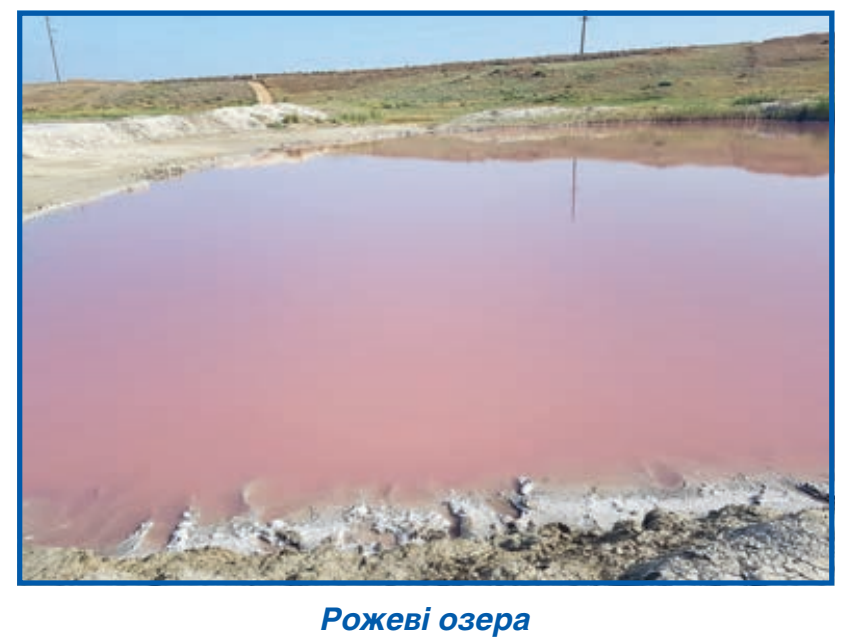


Вилкового. Селище тут у середині XVII століття заснували донські й запорізькі козаки, які зазнавали переслідування царської влади за релігійними та політичними мотивами і змушені були втікати на Дунай. У ті часи територія Дунайського гирла належала Османській імперії, що дуже прихильно поставилася до невірних. Праця тисяч втікачів-старовірів підняла це місто над водами Дунайської заплави.

Другий куточок - це місцевість Затока, що мальовничо розкинулася навколо впадіння Дністровського лиману в Чорне море. Тут споруджений в 1955 році розвідний залізнично-автомобільний міст. Динамічним є лише один центральний фрагмент, що піднімається під час проходження транспорту типу «море-річка» $з$ лиману в Чорне море й у зворотному напрямі.

Рожеві озера, багаті натуральною морською сіллю, в Херсонській області поблизу села Григорівки зачаровують своєю природною красою. Вода в цих озерах містить до $35 \%$ солі (фактично ропа), а під ногами відчуваються іiі кристали. Ці озера мають рожевий колір завдяки наявності водоростей, які виробляють каротиноїди (органічні пігменти). До них належить дуналіела солоноводна (Dunaliella salina) - один із видів галофілів зелених мікроводоростей, що живуть у дуже солоній морській воді. Рожеві озера дуже популярні серед туристів в Австралії (Хіллер), на схід від півострова Зелений мис у Сенегалі, на південному сході Іспанії (Торрев’єха), в Канаді, а також неподалік Баку (Масазір) в Азербайджані.

Ще один магічний куточок - Джарилгач, найбільший чудо-острів України та Чорного моря, крім того, це найбілыший незаселений острів Свропи. Часто після напруженого дня вигукуємо: «Хочу у відпустку на острів на краю світу!» А в Україні, як відомо, можли-

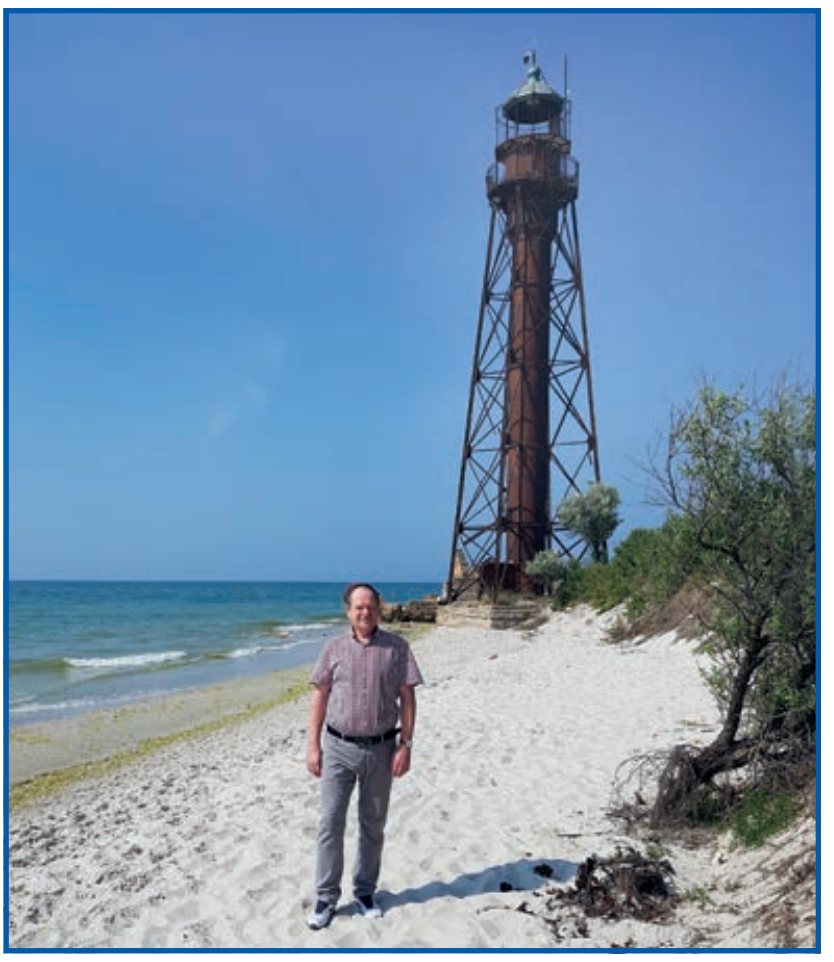

Маяк Ейфеля на острові Джарилгач

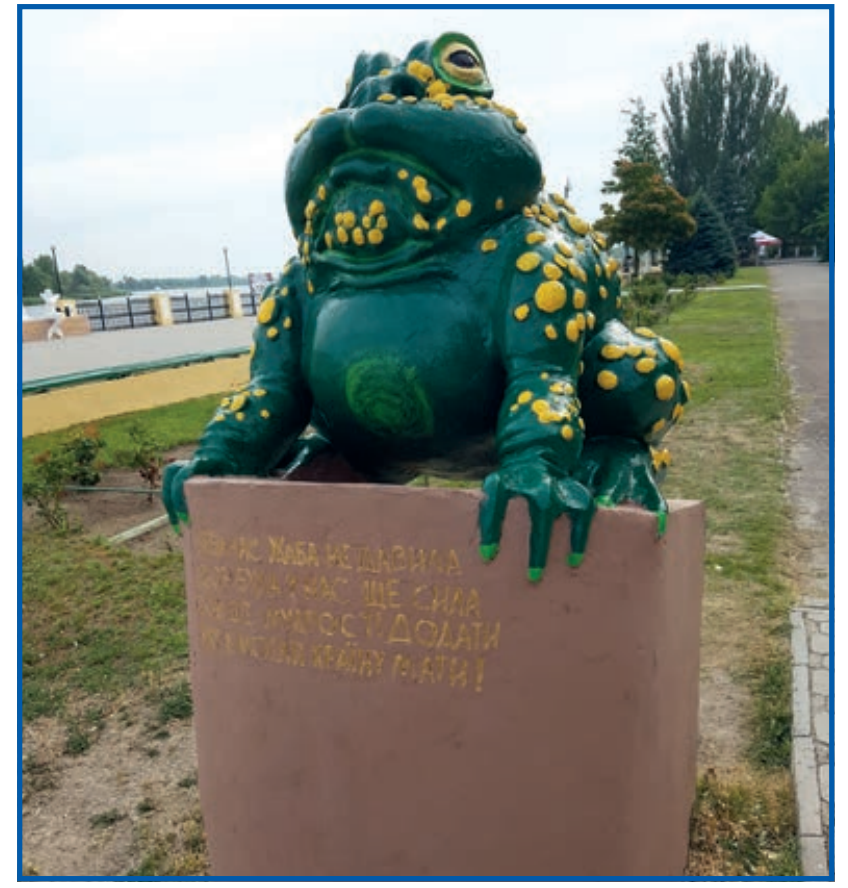

Жаба на набережній в Голій Пристані

во все. Білосніжні пляжі Джарилгача пам'ятають ще за стародавніх греків, але більшість українців не здогадуються про його існування. Острів має видовжену форму із заходу на схід, на заході продовжується довгою піщаною косою, яку від суходолу відділяє вузька протока, що інколи пересихає, формально перетворюючи острів на півострів. Загальна протяжність острова із заходу на схід становить близько 42 км. Родзинкою морської подорожі із Скадовська $€$ можливість побачити грайливі зграйки дельфінів у природних умовах, а на самому острові - засилля різної живності - плазуючої, бігаючої, стрибаючої, літаючої й плаваючої.

До того ж на острові з 1902 року розміщений спроектований одним з учнів самого Олександра Гюстава Ейфеля маяк (за даними окремих авторів, і ним самим). Джарилгач відомий своїми лікувальними грязями та солоними озерами, вода в яких має високий уміст йоду. Усе це справді робить Джарилгач гідною альтернативою поїздці на екзотичні острови. Його вже іноді називають українськими Мальдівами. Це місце - для тих, хто цінує спокій і тишу, а час, проведений наодинці з природою, вважає найкращим відпочинком. Жодної інфраструктури, крім маяка, кількох джерел і шезлонгів, тут немає. Тому вже в другій половині дня слід встигнути на катер до континенту.

А побажаннями будуть слова на постаменті під скульптурою Жаби на набережній одного з рукавів Дніпра в Голій Пристані поблизу Херсона.

Якби нас Жаба не давила,

І шоб була у нас ще сила,

Якби ще мудрості додати,

Яку б могли країну мати!.

Головний редактор професор Володимир Іванович Паньків 